九州大学学術情報リポジトリ

Kyushu University Institutional Repository

\title{
Study on Korean Pine Nut Processors
}

\section{Kang, Hag Mo}

Department of Forest Environmental Science, Chonbuk National University

Choi, Soo Im

Department of Forest Resources, Sunchon National University

Sato, Noriko

Laboratory of Forest Policy, Division of Forest Environment and Management Sciences, Department of Agro-environmental Sciences, Faculty of Agriculture, Kyushu University

Kim, Hyun

Jeonbuk Forest Environment Research Institute

https://doi.org/10.5109/25211

出版情報：九州大学大学院農学研究院紀要. 57 (2)，pp.489-498，2012-09-20. Faculty of Agriculture, Kyushu University

バージョン :

権利関係 : 


\title{
Study on Korean Pine Nut Processors
}

\section{Hag Mo KANG ${ }^{1}$, Soo Im $\mathrm{CHOI}^{2}$, Noriko SATO and Hyun KIM ${ }^{3 *}$}

\author{
Laboratory of Forest Policy, Division of Forest Environment and Management Sciences, \\ Department of Agro-environmental Sciences, Faculty of Agriculture, \\ Kyushu University, Fukuoka 812-8581, Japan \\ (Received April 27, 2012 and accepted May 10, 2012)
}

\begin{abstract}
In the results of survey on operating state of pine nut processors located in Gapyeong-gun, Gyeonggi-do and Hongcheon-gun, Gangwon-do, representative pine nut producing area, the total purchasing amount of pine nuts with a cone of Gapyeong-gun, Gyeonggi-do was 500 4,000 bags ( 1 bag is $80 \mathrm{~kg}$ ), of which average amount per processor was 2000 bags. The price range per bag of pine nuts was 470 620 thousand won and the average price was 550 thousand won. Total purchase price of pine nuts with a cone per processor averaged 1.2 billion won and the mean net income per bag of pine nuts with a cone was 35 thousand won. Total purchasing amount of pine nuts with a cone of Hongcheon-gun, Gangwon-do was 1,000 2,000 bags, averaging 1,500 bags per processor and the price range per bag of pine nuts with a cone was 580 630 thousand won, averaging 610 thousand won. Total purchase price of pine nuts with a cone per processor averaged 0.9 billion won and the mean net income per bag of pine nuts with a cone was 100 thousand won. However, 9 processors among total 16 processors answered to plan to maintain the present state because of difficulty in securing material amount of pine nuts with a cone, low profitability, poor selling, lack of equipment introducing fund, and lack of pine nuts purchasing fund for future business scale. Therefore, it was suggested that in order to activate local economy through maintenance and expansion of pine nut processors, financial supports such as low interest loan for expansion of processing amount were necessary in the short run and expansion of new forestation and crown shape control to facilitate seed exploitation as well as work enforcement such as thinning for increase of yield was required in the long run.
\end{abstract}

Keywords: Korea, Korean pine nut, processors, production, sales

\section{INTRODUCTION}

White pine has been used as wood and its seeds also have been used for foods and drugs widely. It is expected that their demand will be expanded as an ecofriendly agricultural product with increase of national people income. Due to continuous reforestation of Pinus Koraiensis Sieb. et Zucc, the yield and production amount of pine nuts were increased dramatically to 1.52 million $\mathrm{kg}$ and 13.2 billion won as of 2006 compared with those of past and imported amount and price of pine nuts were also increased largely to 397 tons and 2.41 million dollars in 2007. However, because of the characteristics of Pinus Koraiensis Sieb. et Zucc, alternate year bearing, the yield of seeds is irregular. In addition, although gathering and production of pine nuts involve many difficulties such as increase of labor cost for gathering them, reduction of yield from global warming, aging of its gathering labor, risks accompanied with its gathering, and price competition with imported products from increase of import, the pine nuts give a large help to local economy as well as collectors, producers, and processors of pine nuts. Nevertheless, there is few or no concrete domestic study on operation of pine nut proc-

\footnotetext{
${ }^{1}$ Department of Forest Environmental Science, Chonbuk National University, Chonju, 561-756, Korea

${ }^{2}$ Department of Forest Resources, Sunchon National University, Suncheon, 540-742, Korea

${ }^{3}$ Jeonbuk Forest Environment Research Institute, Jinan-gun, 561-756, Korea

* Corresponding author (E-mail: kh4548@korea.kr)
}

essors such other than the study on crown shape control of Pinus koraiensis S. et Z, (Jae Seon Yi et al., 2002) with direct relation to the yield of pine nuts.

Thus, the purpose of this study is to seek future developmental direction by investigating the operation state of pine nut processors located in Korean representative producing districts of pine nuts such as Gapyeonggun, Gyeonggi-do and Hongcheon-gun, Gangwon-do.

\section{MATERIALS AND METHODS}

As of 2008, there were 16 and 4 pine nut processors in Gapyeong-gun, Gyeonggi-do and Hongcheon-gun, Gangwon-do respectively, but this survey was performed against 14 processors in Gapyeong-gun, Gyeonggi-do and 2 processors in Hongcheon-gun, Gangwon-do, excluding the processors which didn't submit the questionnaire. The survey was performed through personal interview against representatives of the processors from March, 2008 to June, 2008. Contents of the survey included general state of processors such as investment, operation period, and processing facility scale, and purchasing source, processing scale, sales income, and sales system of pine nuts. In order to understand overall state of the target districts including area of Korean white pine forest, pine nut yield and processors, we visited provincial forest administration team of Gyeonggi-do Forestry Environment Research Institute, county office of Gapyeong-gun, Gyeonggi-do, country office of Hongcheon, Gangwon-do, and Hongcheon National Forest Station to listen the opinion of officer and obtain associated data. 


\section{RESULTS AND DISCUSSIONS}

\section{Production state of pine nuts in Korea}

Areas of white pine forest by regions

Total area of needle forest and broad-leaf forest in Korea, 4,355 thousand ha, consists of 2,695 thousand (62\%) of needle forest and 1,660 thousand ha (38\%) of broad leaf forest. The White pine forest took 5 of total forest area and $9 \%$ of needle forest and by regions, Gangwon-do has 77 thousand ha, followed by Gyeonggi-do with 66 thousand ha and Gyeongsangbuk-do with 28 thousand ha. The district with higher ratio of White pine forest in needle forest was Gyeonggi-do having the highest ratio of White pine forest as 34\%, followed by Gangwon-do with $16 \%$ and Chungcheongbuk-do with 11\% (Korea Forest Service, 2007) (Table 1).

Production state of pine nuts with a cone by regions

In the survey on production amount and price of pine-nuts with a cone by years, it was found that the production amount increased from 0.68 million $\mathrm{kg}$ in 2002 to 1.52 million $\mathrm{kg}$ in 2006 and the average annual production amount for 5 years from 2002 to 2006 was 2.04 mil-

Table 1. Area unit of White pine forest by regions

(Unit: thousand ha)

\begin{tabular}{|c|c|c|c|c|c|c|c|c|}
\hline \multirow{2}{*}{ Classification } & \multirow{2}{*}{ Total } & \multicolumn{6}{|c|}{ Needle-leaf trees } & \multirow{2}{*}{$\begin{array}{c}\text { Broad- leaf } \\
\text { trees }\end{array}$} \\
\hline & & Sub-total & Pine & Larch & Rigida & White pine & Others & \\
\hline Total & 4,355 & $\begin{array}{l}2,695 \\
(100)\end{array}$ & 1,481 & 464 & 411 & $\begin{array}{l}231 \\
(9)\end{array}$ & 116 & 1,660 \\
\hline Gyeonggi-do & 381 & $\begin{array}{c}194 \\
(100)\end{array}$ & 12 & 51 & 64 & $\begin{array}{c}66 \\
(34)\end{array}$ & 1 & 187 \\
\hline Gangwon-do & 945 & $\begin{array}{c}475 \\
(100)\end{array}$ & 252 & 140 & 3 & $\begin{array}{c}77 \\
(16)\end{array}$ & 3 & 470 \\
\hline Chungcheongbuk-do & 350 & $\begin{array}{c}232 \\
(100)\end{array}$ & 48 & 111 & 46 & $\begin{array}{c}26 \\
(11)\end{array}$ & 1 & 118 \\
\hline Chungcheongnam-do & 317 & $\begin{array}{c}201 \\
(100)\end{array}$ & 81 & 15 & 94 & $\begin{array}{c}9 \\
(5)\end{array}$ & 2 & 116 \\
\hline Jeollabuk-do & 346 & $\begin{array}{c}198 \\
(100)\end{array}$ & 95 & 21 & 62 & $\begin{array}{l}13 \\
(7)\end{array}$ & 7 & 148 \\
\hline Jeollanam-do & 524 & $\begin{array}{c}395 \\
(100)\end{array}$ & 250 & - & 69 & $\begin{array}{c}4 \\
(1)\end{array}$ & 72 & 129 \\
\hline Gyeongsangbuk-do & 806 & $\begin{array}{c}564 \\
(100)\end{array}$ & 416 & 94 & 22 & $\begin{array}{l}28 \\
(5)\end{array}$ & 4 & 242 \\
\hline Gyeongsangnam-do & 459 & $\begin{array}{c}314 \\
(100)\end{array}$ & 250 & 27 & 25 & $\begin{array}{c}5 \\
(2)\end{array}$ & 7 & 145 \\
\hline Others & 228 & $\begin{array}{c}130 \\
(100)\end{array}$ & 77 & 5 & 26 & $\begin{array}{c}3 \\
(2)\end{array}$ & 19 & 98 \\
\hline
\end{tabular}

Source: Forest Service. 2007 Statistical Yearbook of Forestry

Note: The value in ( ) is the component ratio.

Table 2. Production record of pine nuts with a cone by regions

(Unit: 10,000 kg, 100 million won)

\begin{tabular}{|c|c|c|c|c|c|c|c|c|c|c|}
\hline \multirow{2}{*}{ Classification } & \multicolumn{2}{|c|}{2002} & \multicolumn{2}{|c|}{2003} & \multicolumn{2}{|c|}{2004} & \multicolumn{2}{|c|}{2005} & \multicolumn{2}{|c|}{2006} \\
\hline & Quantity & Amount & Quantity & Amount & Quantity & Amount & Quantity & Amount & Quantity & Amount \\
\hline Total & $\begin{array}{c}67.7 \\
(100)\end{array}$ & 64.5 & $\begin{array}{l}226.3 \\
(100)\end{array}$ & 169.5 & $\begin{array}{l}306.3 \\
(100)\end{array}$ & 162.1 & $\begin{array}{l}268.0 \\
(100)\end{array}$ & 213.7 & $\begin{array}{l}151.8 \\
(100)\end{array}$ & 132.3 \\
\hline Gangwon-do & $\begin{array}{l}34.1 \\
(50)\end{array}$ & 32.5 & $\begin{array}{l}70.1 \\
(31)\end{array}$ & 38.5 & $\begin{array}{c}164.9 \\
(54)\end{array}$ & 82.6 & $\begin{array}{c}162.7 \\
(61)\end{array}$ & 120.0 & $\begin{array}{l}97.2 \\
(64)\end{array}$ & 73.7 \\
\hline Gyeonggi-do & $\begin{array}{l}19.8 \\
(29)\end{array}$ & 18.8 & $\begin{array}{c}137.6 \\
(61)\end{array}$ & 110.2 & $\begin{array}{c}123.9 \\
(41)\end{array}$ & 61.9 & $\begin{array}{l}90.2 \\
(34)\end{array}$ & 69.5 & $\begin{array}{l}41.5 \\
(27)\end{array}$ & 34.7 \\
\hline Gyeongsangnam-do & 5.7 & 5.4 & 3.9 & 3.2 & 5.5 & 4.7 & 6.9 & 5.4 & 6.9 & 5.7 \\
\hline Gyeongsangbuk-do & 2.6 & 2.5 & 2.3 & 7.4 & 0.6 & 1.1 & 3.3 & 3.2 & 0.5 & 0.8 \\
\hline Jeollabuk -do & 3.8 & 3.6 & 3.9 & 3.1 & 3.4 & 4.7 & 3.1 & 10.4 & 3.0 & 13.0 \\
\hline Chungcheongbuk-do & 1.1 & 1.1 & 0.7 & 3.7 & 0.8 & 4.0 & 0.8 & 3.5 & 0.7 & 3.1 \\
\hline Others & 0.6 & 0.6 & 7.8 & 3.4 & 7.2 & 3.1 & 1.8 & 1.7 & 2.0 & 1.3 \\
\hline
\end{tabular}

Source: Forest Service. 2007 Statistical Yearbook of Forestry

Note: The value in ( ) is the longitudinal component ratio. 
lion kg. By regions, its production amount in Gangwon-do has increased every year and occupied $64 \%$ of total production amount as 0.97 million $\mathrm{kg}$ in 2006 and the average annual production for last 5 years was 1.06 million $\mathrm{kg}$. Its production amount of Gyeonggi-do showed large increase every year and occupied $27 \%$ of total production amount as 0.42 million $\mathrm{kg}$ in 2006. The average annual production for last 5 years was 0.83 million $\mathrm{kg}$. Besides, it was also reported that its production amount increased largely from 6.5 billion won in 2002 to 13.2 billion won in 2006 and the average annual production amount was 14.8 billion won. By regions, its production amount of Gangwon-do has increased every year and occupied 56\% of total production amount as 7.4 billion won in 2006. The average annual production for last 5 years was 6.9 billion won. For Gyeonggi-do, it accounted for $26 \%$ of total production amount as 3.5 billion won in 2006 and the average annual production amount for last 5 years was 5.9 billion won (Korea Forest Service, 2007) (Table 2).

\section{Export and import of pine nuts by years}

For imported pine nuts, frozen pine nuts had accounted for $91 \%$ and $86 \%$ of the imported quantity and amount respectively for 8 years, from 2000 to 2007, but only frozen pine nuts has been imported since 2006 Import scale of frozen pine nuts increased largely from 64 tons and 0.15 million dollars in 2006 to 397 tons and 2.41 million dollars and is delivered from China. Majority of pine nuts with a cone were imported from USA and shelled pine nuts were imported from China respectively. For exported pine nuts, its scale had been minor as only 18 tons and 0.24 million dollars in total export quantity and amount respectively for 8 years and it was found that there was no export record since 2005 (Korea Forest Service, 2008) (Table 3).

\section{Production state of pine nuts in subject areas} Forest areas and White pine forest by ownerships

First, for the forest areas of Gapyeong-gun, Gyeonggi-do and Hongcheon-gun, Gangwon-do, where the subject processors were located by ownerships, it was found that Gapyeong-gun, Gyeonggi-do consisted of $54 \%$ of private forest, $32 \%$ of provincial forest, $13 \%$ of national forest, and 1\% of military forest in 69 thousand ha of total forest area, where White pine forest accounted for $30 \%$ of total forest area. The area ratio of White pine forest by ownerships consisted of 38\% of private forest, $24 \%$ of provincial forest, and $13 \%$ of national forest. It

Table 3. Export and import record of pine nuts by years

(Unit: tons, thousand dollars)

\begin{tabular}{|c|c|c|c|c|c|c|c|c|c|c|c|c|c|c|}
\hline & & & & $\operatorname{Imp}$ & ort & & & & & & & & & \\
\hline & To & tal & Frozen & ine nuts & Shelled & ne nuts & pine & with a & & & Shelle & ne nuts & pine & ith a \\
\hline & Quantity & Amount & Quantity & $\overline{\text { Amount }}$ & Quantit & Amount & Quant & $\overline{\text { Amount }}$ & Quanti & $\overline{\text { Amount }}$ & Quanti & $\overline{\text { mount }}$ & Quant & nount \\
\hline Total & $\begin{array}{l}1,223 \\
(100)\end{array}$ & $\begin{array}{l}6,457 \\
(100)\end{array}$ & $\begin{array}{c}1,117 \\
(91)\end{array}$ & $\begin{array}{c}5,580 \\
(86)\end{array}$ & 103 & 614 & 3 & 263 & 18 & 25 & 12 & 24 & 6 & 1 \\
\hline 2000 & 1 & 20 & - & - & 1 & 20 & - & - & - & - & - & - & - & - \\
\hline 2001 & 13 & 93 & - & - & 13 & 93 & - & - & - & - & - & - & - & - \\
\hline 2002 & 129 & 337 & 64 & 146 & 55 & 191 & - & - & 10 & 19 & 10 & 19 & - & - \\
\hline 2003 & 60 & 420 & 44 & 126 & 14 & 168 & 2 & 126 & - & - & - & - & - & - \\
\hline 2004 & 128 & 402 & 120 & 402 & - & - & - & - & 8 & 6 & 2 & 5 & 6 & 1 \\
\hline 2005 & 259 & 1,189 & 238 & 910 & 20 & 142 & 1 & 137 & - & - & - & - & - & - \\
\hline 2006 & 254 & 1,586 & 254 & 1,586 & - & - & - & - & - & - & - & - & - & - \\
\hline 2007 & 397 & 2,410 & 397 & 2,410 & - & - & - & - & - & - & - & - & - & - \\
\hline
\end{tabular}

Source: Korea Forest Service. 2008 Export and Import Statistics on Forest Products

Note: Less than 1 ton of export and import quantity was excluded from the statistics.

Table 4. Forest area in the subject regions by ownerships

(Unit: ha)

\begin{tabular}{cccccc}
\hline Classification & Total & National forest & Provincial forest & Military forest & Private forest \\
\hline \multirow{2}{*}{ Gapyeong-gun } & 69,193 & 8,718 & 22,419 & 834 & 37,222 \\
& $(20,651)$ & $(1,173)$ & $(5,385)$ & $($ unclear) & $(14,093)$ \\
Hongcheon-gun & 149,582 & 84,658 & 5,114 & 5,123 & $(292)$ \\
\hline
\end{tabular}

Source: 1. Forest Service. 2007 Statistical Yearbook of Forestry

2. Gapyeong-gun. 2008 Planted area of White pine

3. Hongcheon-gun. 2008 Planted area of White pine

4. Gyeonggi-do Forestry Environment Research Institute 2008. Report of pine nut fruiting amount.

Note: The value in ( ) is area of Pinus Koraiensis Sieb. et Zucc. 
was found also that Hongcheon-gun, Gangwon-do had 150 thousand ha of total forest area, which consisted of $57 \%$ of national forest, $37 \%$ of private forest, $3 \%$ of military forest, and $3 \%$ of provincial forest and White pine forest accounted for $19 \%$ of total forest area. The area ratio of White pine forest by ownerships consisted of 38\% of private forest, $8 \%$ of national forest, and $6 \%$ of military forest (Gapyeong-gun, 2008a; Hongcheon-gun, 2008a; Gyonggi-do Forest Environment Research Station, 2008a) (Table 4).

Harvest status of pine nuts with a cone by ownerships

First, Gapyeong-gun, Gyeonggi-do had 3,705 thousand $\mathrm{kg}$ of total pine nuts with a cone harvest for 6 years from 2002 to 2007, of which annual mean was 618 thousand kg. Each harvest by ownerships for total harvest quantity consisted of $93 \%$ of private forest and $7 \%$ of provincial forest. The average annual yielding quantity was 574 thousand $\mathrm{kg}$ of the private forest, 41 thousand $\mathrm{kg}$ of the provincial forest and 2 thousand $\mathrm{kg}$ of the national forest. The national forest located in Gapyeong-gun concluded a profit sharing agreement to divide the yield in 2007 into $70 \%$ and $30 \%$ with 40 persons in 5 villages and each share of national forest and collector earned 6.5 million won and 15.18 million won of income respectively. On the other hand, Gapyeong-gun had concluded a profit sharing agreement to divide profit into 7:3 between collectors and Gapyeong-gun for 25 ha of White pine forest (yield of pine nuts with a cone $560 \mathrm{~kg}$ ) in 2007 for the first time. In addition, it is promoting the geographical indication system of Gapyeong pine nuts for preventing inflow of pine nuts from other regions and making a brand of pine nuts produced in Gapyeong as of 2008. Hongcheon-gun, Gangwon-do had 5,248 thousand $\mathrm{kg}$ of total harvest for 6 years from 2002 to 2007, of which annual mean was 875 thousand kg. The harvest amount by ownerships for the total harvest were $99 \%$ of private and public forest and 1\% of national forest, and each annual mean harvest was 865 thousand kg of pri- vate and public forest and 10 thousand $\mathrm{kg}$ of national forest (Gapyeong-gun, 2008b; Hongcheon-gun, 2008b; Chuncheon National Forest Office, 2008; Hongcheon National Forest Office, 2008b) (Table 5). In the other hand, Hongcheon-gun also had a plan to complete the geographical indication system of Hongcheon pine nuts by 2008 in order to make the pine nuts produced in Hongcheon a brand and to prevent outflow of them in unprocessed state such as bunches and cones of pine nuts. Hongcheon-gun is expanding support on pine nut processing facilities to raise the value-added of pine nuts by processing the whole amount of pine nuts bunches and pine nuts with a cone which are being drained to other regions with low price.

Pine nut production of provincial forest in Gyeonggi-do and Hongcheon National Forest Office

The provincial forest in Gyeonggi-do concludes a profit sharing agreement based on fruiting survey result on pine nut fruiting forest land with trees older than 15 years in its provincial forest every year. The profit sharing ratio between collectors and provincial forest was set as 70\% : 30\% and in 2007, 70 households participated in gathering of pine nuts with a cone from Sep 6 to Oct 31 . From 2002 to 2007, total sale amount of pine nuts with a cone from national forests was 420 million won and its annual mean reached 70 million won (Gyonggi-do Forest Environment Research Station, 2008a; Gyonggi-do Forest Environment Research Station, 2008b) (Table 6).

The national forests in Gangwon-do under the Gangwon-do Hongcheon National Forest Office concludes profit sharing agreements with residents of the corresponding region on the basis of fruiting survey results on pine nut fruiting forest land with trees older than 30 years in the national forest every year. The profit sharing ratio between collectors and national forest was set as 70\% : 30\% In 2007, 36 representatives of collectors (collecting personnel per representative was $6 \sim 12$ persons in average) concluded the profit sharing agree-

Table 5. Gathering state of pine nuts with a cone by ownerships

(Unit: thousand $\mathrm{kg}$ )

\begin{tabular}{|c|c|c|c|c|c|c|c|}
\hline \multirow[b]{2}{*}{ Classification } & \multicolumn{4}{|c|}{ Gapyeong-gun } & \multicolumn{3}{|c|}{ Hongcheon-gun } \\
\hline & Total & $\begin{array}{l}\text { National } \\
\text { forest }\end{array}$ & $\begin{array}{l}\text { Provincial } \\
\text { forest }\end{array}$ & Private forest & Total & National forest & $\begin{array}{l}\text { Public forest } \\
\text { Private forest }\end{array}$ \\
\hline Total & 3,705 & 12 & 247 & 3,446 & 5,248 & 60 & 5,188 \\
\hline Annual mean & 618 & 2 & 41 & 574 & 875 & 10 & 865 \\
\hline 2002 & 18 & - & 3 & 15 & 107 & - & 107 \\
\hline 2003 & 868 & - & 110 & 758 & 429 & 5 & 424 \\
\hline 2004 & 703 & 7 & 60 & 636 & 952 & 6 & 946 \\
\hline 2005 & 550 & - & 3 & 547 & 1,015 & 1 & 1,014 \\
\hline 2006 & 114 & - & 10 & 104 & 288 & 3 & 285 \\
\hline 2007 & 1,452 & 5 & 61 & 1,386 & 2,457 & 45 & 2,412 \\
\hline
\end{tabular}

Source: 1. Gapyeong-gun. 2008 Annual state of pine nuts gathering

2. Hongcheon-gun 2008 The yield of Hongcheon pine nuts

3. Chuncheon National Forest Office. 2008 Internal data

4. Hongcheon National Forest Office. 2008 Internal data

Note: 1. The provincial forest of Gapyeong-gun is sum of pine nut production amount of provincial forests located in 3 cities and provinces such as Gapyeong-gun, Pocheon-si, and Namyangju-si.

2. In 2007, the pine nut production of provincial forest located in Gapyeong-gun accounted for $90 \%$ of total. 
Table 6. Gathering state of pine nuts with a cone in Gyeonggi-do provincial forest

\begin{tabular}{ccccc}
\hline \multirow{2}{*}{ Classification } & \multicolumn{3}{c}{ Gathering amount (thousand kg) } & \multirow{2}{*}{$\begin{array}{c}\text { Sales amount of pine nuts with a cone from } \\
\text { provincial forest (thousand won) }\end{array}$} \\
\cline { 2 - 3 } Total & Total & Regional residents & Provincial forest & \\
Annual mean & 247 & 173 & 74 & 421,135 \\
2002 & 41 & 29 & 12 & 70,189 \\
2003 & 3 & 77 & 33 & 7,544 \\
2004 & 60 & 42 & 18 & 172,545 \\
2005 & 3 & 2 & 1 & 68,457 \\
2006 & 10 & 7 & 3 & 8,772 \\
2007 & 61 & 43 & 18 & 20,445 \\
\hline
\end{tabular}

Source: 1. Gyeonggi-do Forestry Environment Research Institute. 20082007 Pine Nuts Gathering Completion Report of Provincial Forest

2. Gyeonggi-do Forestry Environment Research Institute. 20082007 Report of pine nut fruiting amount

Table 7. Details of pine nuts with a cone gathering of Gangwon-do Hongcheon National Forest Office

\begin{tabular}{|c|c|c|c|c|}
\hline \multirow{2}{*}{ Classification } & \multicolumn{3}{|c|}{ Gathering amount (thousand kg) } & \multirow{2}{*}{$\begin{array}{l}\text { Sales amount of pine nuts with a cone from } \\
\text { national forest (thousand won) }\end{array}$} \\
\hline & Total & Regional residents & National forest & \\
\hline Total & 85.7 & 60.0 & 25.7 & 147,520 \\
\hline Annual mean & 14.3 & 10.0 & 4.3 & 24,587 \\
\hline 2002 & - & - & - & - \\
\hline 2003 & 16.4 & 11.5 & 4.9 & 18,787 \\
\hline 2004 & 20.4 & 14.3 & 6.1 & 21,806 \\
\hline 2005 & 1.4 & 1.0 & 0.4 & 3,350 \\
\hline 2006 & 2.6 & 1.8 & 0.8 & 5,900 \\
\hline 2007 & 44.9 & 31.4 & 13.5 & 97,677 \\
\hline
\end{tabular}

Source: Hongcheon National Forest Office. 2008 Details of Pine Nuts Gathering by Sites (2002 2007).

ment and participated in gathering of pine nuts with a cone from Aug. 23 to Oct. 31. From 2002 to 2007, total sale amount of pine nuts with a cone from provincial forests was 150 million won and its annual mean reached 25 million won (Hongcheon National Forest Office, 2008b) (Table 7). However, the profit sharing ratio between collectors and national forest was changed to $90 \%: 10 \%$ and Hongcheon National Forest Office made it obligation in concluding the agreement that total personnel participating in gathering works of pine nuts should subscribe in Workmen's Accident Compensation Insurance in order to prepare themselves against accidents that might occur during the collecting works. Gyeonggi-do provincial forests and National Forest Office located in Gapyeong gun also made it obligation to subscribe in insurances against accidents.

\section{Case Study}

General state and processing state of pine nut processors

\section{General state of pine nut processors}

For the subjects, 14 pine nut processors in Gapyeonggun, Gyeonggi-do and 2 pine nut processors in Hongcheon-gun, Gangwon-do, it was found that 12 and 2 processors were being operated as private and corporate form respectively. Their operation periods were 5 35 years averaging 17 years and the age of representative were 36 72 years old, averaging 53 years old.
Investment amount was 0.3 billion won per processor on the average, average area per processor was 370, and average number of their employees was 10, of which temporary employment accounted the majority as 7.2 processors located in Hongcheon-gun, Gangwon-do were being operated by individuals and their operation periods were 3 and 23 years respectively. Average age of their representatives was 51 years old, their average investment amount was 0.7 billion won, and average area of their processing facilities was 440. Average number of their employees was 9 , but temporary employment accounted for the majority as 7 persons. For the reason that the majority of their employment were temporary, the processors of Gapyeong-gun and Hongcheon-gun answered to control the processing quantity considering purchase quantity, sales demand and price of pine nuts with a cone and the periods of their employment were diverse as 4 10 months. Moreover, although 2 of 3 corporations in Gapyeong-gun received partial support, other processors received no support. 2 processors in Hongcheon-gun constructed a new building and introduced automated processing equipments with 0.2 billion won of support from Hongcheon-gun and their own share respectively in 2006 .

Processing and income state of pine nuts with a cone

First, total purchasing amount of pine nuts with a cone of Gapyeong-gun, Gyeonggi-do was 500 4,000 bags ( 1 bag is $80 \mathrm{~kg}$ ) of which average amount per proc- 
essor was 2000 bags. Price range per bag of pine nuts was 470 620 thousand won and the average price was 550 thousand won. Total purchase price of pine nuts with a cone per processor averaged 1.2 billion won and the mean net income per bag of pine nuts with a cone was 35 thousand won.

Total purchasing amount of pine nuts with a cone of Hongcheon-gun, Gangwon-do to process them into shelled pine nuts was 1,000 2,000 bags, averaging 1,500 bags per processor and the price range per bag of pine nuts with a cone was 580 630 thousand won, averaging 610 thousand won. Total purchase price of pine nuts with a cone per processor was 0.9 billion won on the average and the mean net income per bag of pine nuts with a cone was 100 thousand won. On the other hand, most of processors in Gapyeong-gun and Hongcheon-gun answered that they hoped to expand their income by increasing the processing quantity, but it was not easy because of difficulties in expansion of markets and funding money for purchasing pine nuts with a cone.

Purchase method of pine nuts with a cone and sales method of shelled pine nuts

Purchase and producing district of pine nuts with a cone

In purchase of pine nuts Gapyeong-gun, Gyeonggi-do, individual collectors and collecting merchants accounted for $90 \%$ and direct gathering of processors was only $10 \%$. In the producing districts, Gyeonggi districts accounted for $74 \%$ and the rest was produced in Gangwon-do including Hongcheon-gun. In case of Hongcheon-gun, total quantity of pine nuts with a cone was purchased from individual collectors and collecting merchants and the producing district of whole quantity was Hongcheon different from Gapyeong-gun. Like this, it was considered that the reason that processors in Gapyeong-gun purchased pine nuts from Gangwon-do was that the quantity of pine nuts with a cone produced in Gapyeong-gun was insufficient compared with their processing capacity and the reason that pine nuts from Hongcheon-gun were flown into Gapyeong-gun, their production was greater than their processing capacity. Sales method of shelled pine nuts

Sales method of shelled pine nuts of Gapyeong-gun, Gyeonggi-do consisted of 37\% of wholesale market, 30\% of retail and individual delivery, and 17\% of internet and e-post shopping. Besides, the sales manner of Hongcheon-gun, Gangwon-do consisted of 33\% of company, $30 \%$ of wholesale market, and $17 \%$ of internet and e-post shopping.

However, whereas Gapyeong-gun sold most of their shelled pine nuts with a mark of Gapyeong pine nuts but sold a part of them with indication of "Made in Korea". The reason was that all of them were not produced in Gapyeong-gun but produced in other districts of Gyeonggi-do and Gangwon-do. Besides, it was found that a part of pine nuts labeled with Produced in Gapyeong were processed in mixture of pine nuts with a cone produced in Gapyeong and other districts. On the other hand, 6 processors of 14 processors in Gapyeonggun had their shops on the roadside with large traffic to facilitate sale of pine nuts. However, in case of Hongcheon-gun, all the 4 processors performing processing of pine nuts currently were located in places with little traffic, so it was difficult to appeal to drivers and visi-

Table 8. Operation form and scale of processing facility

\begin{tabular}{|c|c|c|c|c|c|c|c|c|c|c|c|}
\hline \multirow{3}{*}{\multicolumn{2}{|c|}{ Classification }} & \multirow{3}{*}{$\begin{array}{l}\text { Operation } \\
\text { form }\end{array}$} & \multirow{3}{*}{$\begin{array}{l}\text { Operation } \\
\text { period } \\
\text { (year) }\end{array}$} & \multirow{3}{*}{$\begin{array}{l}\text { Age of } \\
\text { representative } \\
\text { (years old) }\end{array}$} & \multirow{3}{*}{$\begin{array}{l}\text { Investor } \\
\text { (person) }\end{array}$} & \multirow{3}{*}{$\begin{array}{l}\text { Investment } \\
\text { amount } \\
\text { (10 million } \\
\text { won) }\end{array}$} & \multirow{3}{*}{$\begin{array}{c}\text { Area of } \\
\text { processing } \\
\text { facility } \\
\left(\mathrm{m}^{2}\right)\end{array}$} & \multicolumn{4}{|c|}{ Employee (person) } \\
\hline & & & & & & & & \multirow{2}{*}{ Total } & \multirow{2}{*}{ House } & \multicolumn{2}{|c|}{ Employment } \\
\hline & & & & & & & & & & Regular & Temporary \\
\hline \multirow{16}{*}{$\begin{array}{l}\text { Gapyeong } \\
\text {-gun }\end{array}$} & Total & - & - & - & 53 & 383.9 & 5,170 & 139 & 41 & 5 & 93 \\
\hline & Average & - & 17 & 53 & - & 29.5 & 369 & 9.9 & 2.9 & 0.4 & 6.6 \\
\hline & 1 & Corporation & 8 & 48 & 27 & 64.0 & 746 & 10 & 1 & 3 & 6 \\
\hline & 2 & Corporation & 7 & 45 & 6 & 94.0 & 419 & 15 & 6 & - & 9 \\
\hline & 3 & Corporation & 8 & 61 & 1 & 113 & 990 & 10 & & 2 & 8 \\
\hline & 4 & Individual & 6 & 60 & 1 & 15.0 & 149 & 8 & 4 & - & 4 \\
\hline & 5 & Individual & 35 & 64 & 1 & 6.0 & 198 & 15 & 4 & - & 11 \\
\hline & 6 & Individual & 10 & 51 & 1 & 21.0 & 413 & 9 & 3 & - & 6 \\
\hline & 7 & Individual & 28 & 36 & 1 & 15.0 & 165 & 11 & 4 & - & 7 \\
\hline & 8 & Individual & 13 & 45 & 1 & 16.4 & 185 & 7 & 3 & - & 4 \\
\hline & 9 & Individual & 20 & 53 & 1 & 1.0 & 215 & 6 & 3 & - & 3 \\
\hline & 10 & Individual & 25 & 72 & 1 & 7.0 & 541 & 14 & 5 & - & 9 \\
\hline & 11 & Individual & 10 & 59 & 1 & 5.0 & 139 & 6 & 1 & - & 5 \\
\hline & 12 & Individual & 18 & 48 & 1 & 20.0 & 238 & 9 & 3 & - & 6 \\
\hline & 13 & Cropunit & 5 & 48 & 9 & 6.5 & 343 & 8 & 2 & - & 6 \\
\hline & 14 & Individual & 25 & 55 & 1 & - & 429 & 11 & 2 & - & 9 \\
\hline \multirow{4}{*}{$\begin{array}{l}\text { Hongcheon- } \\
\text { gun }\end{array}$} & Total & - & - & - & 2 & 145.0 & 878 & 18 & 3 & 1 & 14 \\
\hline & Average & - & 13 & 51 & 1 & 72.5 & 439 & 9.0 & 1.5 & 0.5 & 7 \\
\hline & 1 & Individual & 23 & 47 & 1 & 75.0 & 406 & 8 & 1 & - & 7 \\
\hline & 2 & Individual & 3 & 55 & 1 & 70.0 & 472 & 10 & 2 & 1 & 7 \\
\hline
\end{tabular}

Note: 1. No answer was excluded from the average.

2. The area of processing facility involves buildings for processing equipments, low temperature storehouses, and offices. 
Table 9. Purchasing and processing income of pine nuts with a cone

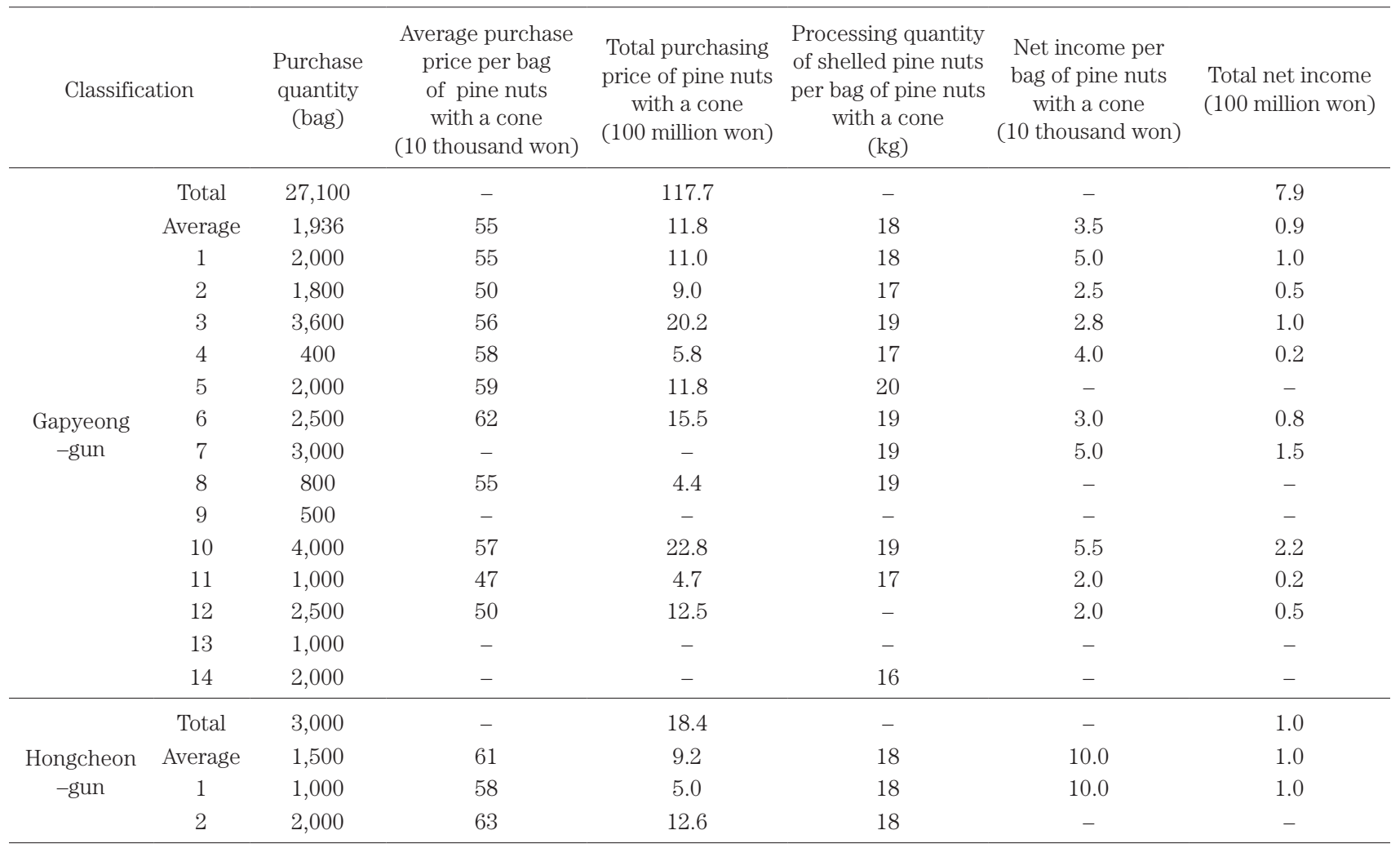

Note: 1 . No answer was excluded from the average. $2.1 \mathrm{bag}$ is $80 \mathrm{~kg}$.

Table 10. Purchase method and producing district of pine nuts with a cone

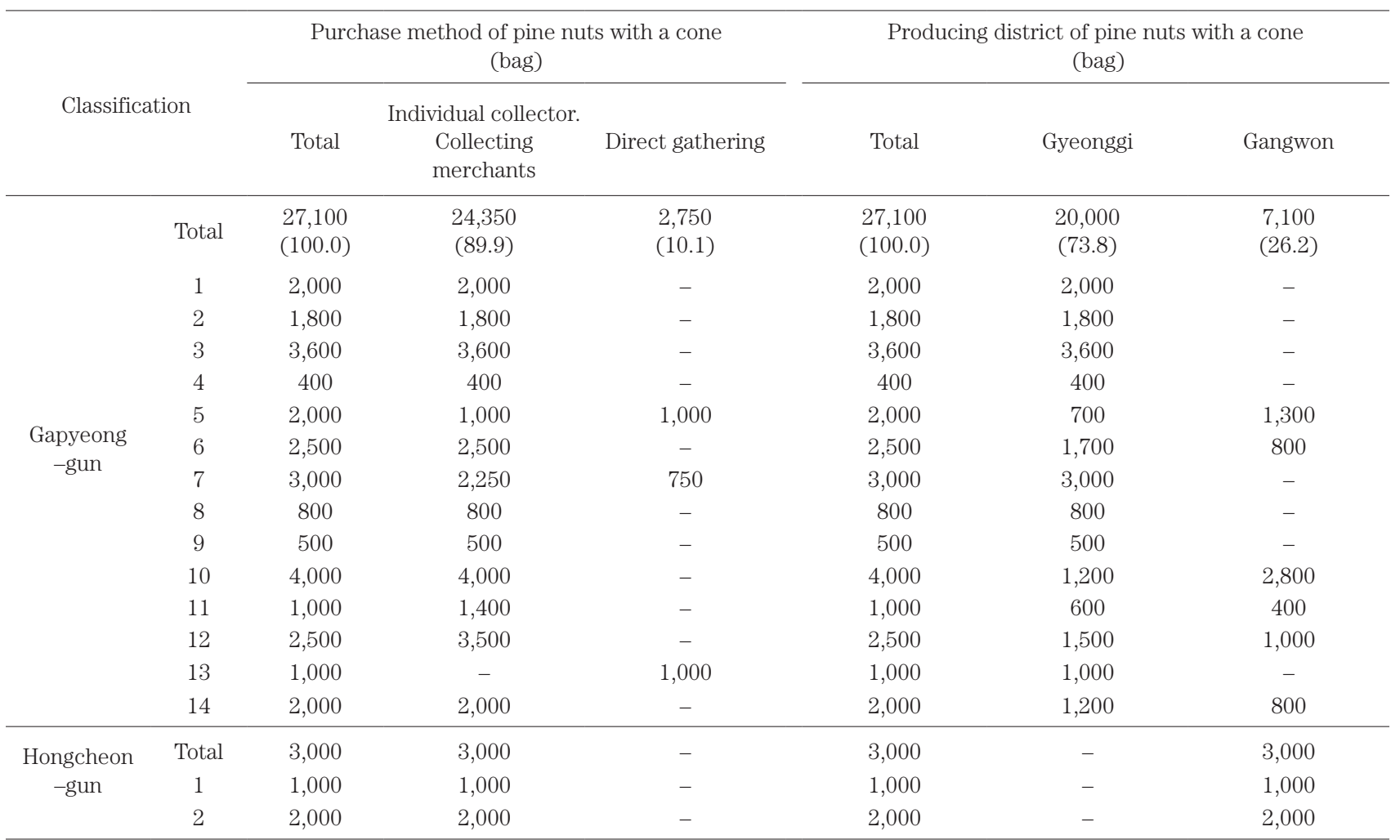

Note: 1.1 bag is $80 \mathrm{~kg}$.

2 . The value in ( ) is the component ratio. 
Table 11. Sales method of shelled pine nuts

(Unit: thousand kg)

\begin{tabular}{|c|c|c|c|c|c|c|c|}
\hline \multicolumn{2}{|c|}{ Classification } & \multirow{2}{*}{$\begin{array}{l}\text { Total } \\
498.7 \\
(100)\end{array}$} & \multirow{2}{*}{$\begin{array}{c}\text { Wholesale } \\
\text { market } \\
\begin{array}{c}185.1 \\
(37)\end{array}\end{array}$} & \multirow{2}{*}{$\begin{array}{c}\begin{array}{c}\text { Retail and individual } \\
\text { delivery }\end{array} \\
\begin{array}{c}147.6 \\
(30)\end{array}\end{array}$} & \multirow{2}{*}{$\begin{array}{c}\begin{array}{c}\text { Internet and } \\
\text { e-post shopping }\end{array} \\
\begin{array}{c}86.7 \\
(17)\end{array}\end{array}$} & \multirow{2}{*}{$\begin{array}{c}\begin{array}{c}\text { Individual } \\
\text { store }\end{array} \\
\begin{array}{c}45.5 \\
(9)\end{array}\end{array}$} & \multirow{2}{*}{$\begin{array}{c}\text { Company } \\
\begin{array}{c}33.8 \\
(7)\end{array}\end{array}$} \\
\hline \multirow{15}{*}{$\begin{array}{l}\text { Gapyeong } \\
\text {-gun }\end{array}$} & Total & & & & & & \\
\hline & 1 & 36.0 & 12.6 & - & 23.4 & - & - \\
\hline & 2 & 30.6 & 29.1 & 1.5 & - & - & - \\
\hline & 3 & 68.4 & - & 68.4 & - & - & - \\
\hline & 4 & 6.8 & 4.1 & - & - & 2.7 & - \\
\hline & 5 & 40.0 & 32.0 & 8.0 & - & - & - \\
\hline & 6 & 47,6 & 9.5 & 23.8 & - & 14.3 & - \\
\hline & 7 & 57.1 & 11.4 & - & 14.3 & 20.0 & 11.4 \\
\hline & 8 & 15.2 & 9.1 & 1.5 & 4.6 & - & - \\
\hline & 9 & 9.0 & 6.3 & 2.7 & - & - & - \\
\hline & 10 & 76.0 & 22.8 & 15.2 & 38.0 & - & - \\
\hline & 11 & 17.0 & - & 8.5 & - & 8.5 & - \\
\hline & 12 & 45.0 & 36.0 & 9.0 & - & - & - \\
\hline & 13 & 18.0 & 9.0 & 9.0 & - & - & - \\
\hline & 14 & 32.0 & 3.2 & - & 6.4 & - & 22.4 \\
\hline \multirow{3}{*}{$\begin{array}{l}\text { Hongcheon } \\
\text {-gun }\end{array}$} & Total & 54.0 & $\begin{array}{l}16.2 \\
(30)\end{array}$ & $\begin{array}{c}7.2 \\
(13)\end{array}$ & $\begin{array}{l}12.6 \\
(23)\end{array}$ & - & $\begin{array}{l}18.0 \\
(33)\end{array}$ \\
\hline & 1 & 18.0 & 5.4 & - & 12.6 & - & - \\
\hline & 2 & 36.0 & 10.8 & 7.2 & - & - & 18.0 \\
\hline
\end{tabular}

Note: The value in ( ) is the component ratio.

tors as indigenous products of Hongcheon-gun. Therefore, it was considered that a method to move the processors to places with great public relation effect or collectivize them would be required in future.

\section{Future management plan of pine nut processors}

First, 14 processors of Gapyeong-gun and 2 processors of Hongcheon-gun answered that their average management goal achievement level was $67 \%$ and it was suggested that their satisfaction level was not so high. For trends of purchase price of pine nuts with a cone, 8 processors among total 16 processors answered that the purchase price was rising and the others answered that they were maintained in current level. For rising factors of the purchase price of pine nuts with a cone, they answered that there were increase of pine nut processors, influx decrease of pine nuts with a cone produced in Gangwon-do, reduction of pine nut production in Gapyeong-gun from temperature rising.

However, for future business scale 6 processors planned expansion, 9 processors planned to maintain the present status, and 1 processor planned reduction. The processors planning expansion expected increase of processing quantity and save of labor cost through introduction and expansion of automated equipments, and the processors planning to maintain the present status answered that there were difficulties in securing of pine nuts with a cone, low profitability, and lack of money for introducing equipments, and lack of money for purchasing pine nuts with a cone, but they would maintain their business for securing income source using family labors in the agricultural off-season. For details of hope on management, the processors of Gapyeong-gun answered to want long term-low interest loan, development of pine nut processing equipment for automation, preparation of measures able to prevent price collusion of pine nuts with a cone by brokers including collecting merchants, enhancement of public relation, packing material support, low temperature storehouse support, and preparing clear criteria of supports for corporations and individuals. The processors of Hongcheon-gun hoped development of automatic equipment such as selection and drying, price control of pine nuts with a cone in alternate year bearing, improvement of sales and distribution structure, and increase of new processors.

\section{CONCLUSION}

1. In Gapyeong-gun, Gyeonggi-do, where subject pine nut processors were located, White pine forest accounted for 30\% of total forest area, 69 thousand ha and in Hongcheon-gun, Gangwon-do, it accounted for 19\% of of total forest area, 150 thousand ha.

2. It was found that Gapyeong-gun, Gyeonggi-do had 3,705 thousand $\mathrm{kg}$ of total harvest for 6 years from 2002 to 2007, of which annual mean was 618 thousand kg. Hongcheon-gun, Gangwon-do had 5,248 thousand $\mathrm{kg}$ of total harvest for 6 years from 2002 to 2007, of which annual mean was 875 thousand $\mathrm{kg}$.

3. In Gapyeong gun, 12 processors and 2 processors among total 14 subject processors were operated in the forms of individual and corporation. Their operation periods were 5 35 years, averaging 17 years and the age of representative were 36 72 years old, averaging 53 years old. Investment amount was 0.3 billion won per processor on average, average area 
per processor was 370, and average number of their employees was 10 , of which temporary employment accounted the majority as 7 .

4. 2 processors located in Hongcheon-gun, Gangwondo were being operated by individuals and their operation periods were 3 and 23 years respectively. Average age of their representatives was 51 years old, their average investment amount was 0.7 billion won, and average area of their processing facilities was 440. Average number of their employees was 9 , but temporary employment accounted for the majority as 7 persons.

5. Total purchasing amount of pine nuts with a cone of Gapyeong-gun, Gyeonggi-do was 500 4,000 bags (1 bag is $80 \mathrm{~kg}$ ), of which average amount per processor was 2000 bags. Price range per bag of pine nuts was 470 620 thousand won and the average price was 550 thousand won. Total purchase price of pine nuts with a cone per processor averaged 1.2 billion won and the mean net income per bag of pine nuts with a cone was 35 thousand won.

6. Total purchasing amount of pine nuts with a cone of Hongcheon-gun, Gangwon-do to process them into shelled pine nuts was 1,000 2,000 bags, averaging 1,500 bags per processor and the price range per bag of pine nuts with a cone was 580 630 thousand won, averaging 610 thousand won. Total purchase price of pine nuts with a cone per processor was 0.9 billion won on the average and the mean net income per bag of pine nuts with a cone was 100 thousand won.

7. In purchase of pine nuts Gapyeong-gun, Gyeonggido, individual collectors and collecting merchants accounted for $90 \%$ and direct gathering of processors was only $10 \%$. In the producing districts of pine nuts with a cone, Gyeonggi districts accounted for $74 \%$ and the rest was produced in Gangwon-do including Hongcheon-gun. In case of Hongcheongun, total quantity of pine nuts with a cone was purchased from individual collectors and collecting merchants and the producing district of whole quantity was Hongcheon different from Gapyeong-gun.

8. Sales method of shelled pine nuts of Gapyeong-gun, Gyeonggi-do consisted of 37\% of wholesale market, $30 \%$ of retail and individual delivery, and $17 \%$ of internet and e-post shopping. Besides, the sales manner of Hongcheon-gun, Gangwon-do consisted of 33\% of company, 30\% of wholesale market, and $17 \%$ of internet and e-post shopping.

9. For future business scale 6 processors planned expansion, 9 processors planned maintaining quo status, and 1 processor planned reduction. The processors planning expansion expected increase of processing quantity and save of labor cost through introduction and expansion of automated equipments, and the processors planning to maintain the present status answered that there were difficulties in securing of pine nuts with a cone, low profitability, and lack of money for introducing equipments, and lack of money for purchasing pine nuts with a cone, but they would maintain their business for securing income source using family labors in the agricultural off-season.

From the above discussions, following challenges were drawn.

1. Although the processors of Gapyeong-gun planned to make Gapyeong pine nuts a brand through geographical indication system, the production of pine nuts with a cone in Gapyeong-gun did not reach their processing capacity. Therefore, it seemed that Gapyeong-gun would need forest practices such as thinning in the short term and crown shape control to facilitate harvesting fruits as well as new forestation in the long term.

2. In case of Hongcheon-gun, it seemed that it is required to grow pine nuts as indigenous products through promotion of geographical indication system for its own pine nuts and fostering and expansion of sales market to raise their value-added by processing total quantity of pine nuts produced in the district.

3. The largest difficulty of processors in both districts was supply of money for purchasing pine nuts with a cone for processing and selling. Therefore, it was considered that when financial support measures such as low interest loan for expansion of processing quantity were prepared to activate the processors, it would be possible to induce positive participation of mountain owners in their management for White pine forest as well as income increase of pine nut collecting and producing agricultural farms.

4. As hoarding and price collusion of brokers including collecting merchants gave great effect on the purchasing price of pine nuts with a cone, it seemed that measures for local governments to purchase pine nuts and supply them to the processors in stable price were needed.

5. In order to overcome the poor sales, it seemed that development of various products using pine nuts and holding events were needed and positive public relation of pine nuts as local indigenous products in places with great advertisement effect was required also.

6. Finally, there were some differences in production and processing capacity of pine nuts with a cone between both regions. In case of Gapyeong-gun, some products didn't have clear indication on their production district and in case of Hongcheon-gun, their pine nuts were discharged to outside because of low price, so changed to products produced in other regions or could not raise their value added. Therefore, both districts should give efforts to differentiate their pine nuts from those produced in other regions and to make them a brand by operating faithfully the systems such as geographical indication system faithfully.

\section{REFERENCES}

Chuncheon National Forest Office. 2008 Internal data 
Gapyeong-gun. 2008a Planted area of White pine

Gapyeong-gun. 2008b Annual state of pine nuts gathering

Gyonggi-do Forest Environment Research Station. 2008a 2007 Report of pine nut fruiting amount

Gyonggi-do Forest Environment Research Station. 2008b 2007 Pine Nuts Gathering Completion Report of Provincial Forest

Hongcheon-gun. 2008a Planted area of White pine

Hongcheon-gun. 2008b The yield of Hongcheon pine nuts
Hongcheon National Forest Office. 2008a Internal data Hongcheon National Forest Office. 2008b Details of Pine Nuts Gathering by Sites (2002 2007)

Jae Seon Yi et al. 2002 Crown Shape Control of Pinus Koraiensis S.et Z. Journal of Korean Forest Society, 91(3): 247-253

Korea Forest Service. 2007 Statistical Yearbook of Forestry Korea Forest Service. 2008 Statistics on export and import of forest products 